\title{
Structural Transformation of Agricultural Waste/Coke Blends and Their Implications during High Temperature Processes
}

\author{
Nur Farhana MOHD YUNOS, ${ }^{1,2)}$ Magdalena ZAHARIA, ${ }^{1)}$ Khairel Rafezi AHMAD, ${ }^{2)}$ Dilip NATH, ${ }^{1)}$ \\ Masanori IWASE ${ }^{3)}$ and Veena SAHAJWALLA ${ }^{1)}$
}

1) Centre for Sustainable Materials Research \& Technology, School of Materials Science and Engineering, The University of New South Wales, Sydney, NSW 2052 Australia. E-mail: n.f.mohdyunos@student.unsw.edu.au

2) School of Materials Engineering, The University of Malaysia Perlis, Kubang Gajah 02600, Perlis, Malaysia.

3) Thermochemistry Research Group, Department of Energy Science and Technology, Kyoto University, Kyoto, 606-8501 Japan.

(Received on November 29, 2010; accepted on April 12, 2011)

\begin{abstract}
With a sharp increase in demand and production, palm oil wastes, (i.e. empty fruit bunches, fibre and shells) are generated, out of which a large amount ends up in landfill. In such a context, alternative solutions are needed to reduce the impact of these agricultural wastes on the environment. The present paper investigates the effect of addition of agricultural waste materials on the combustion behavior of its blends with metallurgical coke (MC). Two types of agricultural waste materials, palm shell and coconut shell, were mixed in different proportion with $\mathrm{MC}$, while the gas phase reactions were studied at $1200^{\circ} \mathrm{C}$ in a drop tube furnace (DTF). In the tested conditions, the blends containing agricultural waste materials indicated higher combustion efficiencies compared to $\mathrm{MC}$ alone. Carbon structure analysis were performed through ${ }^{13} \mathrm{CP} / \mathrm{MAS}$ NMR spectroscopy showing various groups of carbons present in the agricultural waste samples ranging from aliphatic to aromatic carbons. The morphology of the samples was studied through Scanning Electron Microscope (SEM). SEM provided a qualitative description of the pore structure in the raw samples as well as the changes occurring following the gas phase reactions in the DTF. It was found that the particles derived from the wastes became increasingly deformed and lost their cell lumen. Surface area measurements were found to be in good agreement with the SEM images, supporting the higher combustion efficiency of the blends in comparison to coke alone. The present study suggests that agricultural waste materials have the potential to partially replace $\mathrm{MC}$, as an auxiliary fuel in metallurgical processes.
\end{abstract}

KEY WORDS: metallurgical coke; agricultural wastes; combustion; structure transformation.

\section{Introduction}

The metallurgical industries consumes a tremendous amount of energy, with an estimated value of $20-35 \%$ of the annual industrial energy consumption and is one of the largest $\mathrm{CO}_{2}$ emitter accounting for approximately $5 \%$ of the total $\mathrm{CO}_{2}$ emission. ${ }^{1,2)}$ Agricultural waste materials are a renewable source of carbon and a possible replacement for coke used in normally high temperature processes. The use of agricultural wastes, such as (palm and coconut shell) as partial replacement of coke is an attractive solution, since the cellular carbon in these wastes is derived from the usage of carbon dioxide in the atmosphere in the photosynthesis process.

Malaysia is the second largest palm oil producing country in the world, with 30 million tonnes, out of which 8.2 million tonnes are discarded as palm waste, consisting of empty fruit bunches, fibres and palm shells. Approximately 1.9 million tonnes of palm shell were generated in 2000 alone, and a steady $5 \%$ increase was seen in the last years. ${ }^{3)}$ Previously, in order to understand the possible applications of coal/agricultural waste in high temperature industries, a number of studies concerning co-firing, ${ }^{4)}$ co-gasification ${ }^{5)}$ and copyrolysis $^{6,7)}$ of blended fuels of coal and agricultural waste materials have been carried out. Carbon from wood char has been used for iron making in the past ${ }^{8,9}$ while the mini blast furnaces in Brazil use wood char on a daily basis. ${ }^{10)}$

The use of palm shell charcoal for the production of good quality steel was considered by Emmerich et al. ${ }^{11)}$ due to the low amount of phosphorus present in this agricultural waste materials. The palm shell charcoal was seen to possess other advantageous characteristics; e.g. low sulphur and nitrogen content, resulting in low $\mathrm{SO}_{x} / \mathrm{NO}_{x}$ emission; its $\mathrm{CO}_{2}$, reactivity was found to be higher than that of coke, allowing a slightly lower working temperature in the blast furnace. Besides that, the palm shell waste is a true renewable fuel, so it does not contribute to the increase in the global $\mathrm{CO}_{2}$ concentration. $^{12)}$

Coconut shell, Cocos nucifera, consists of a hard and thick bony endocarp material, which presents serious disposal problems in the local environments. ${ }^{13,14)}$ Recycling this unused resource would add to its economic value, helping reduce the cost of waste disposal and most importantly, providing an inexpensive alternative to conventional coke. ${ }^{15,16)}$ 
Table 1. Proximate and ultimate analyses of MC, agricultural wastes and MC/agricultural waste blends samples.

\begin{tabular}{lrrrrrrrrcc}
\hline & \multicolumn{3}{c}{ Proximate Analysis (\%) } & \multicolumn{5}{c}{ Ultimate Analysis (\%) } \\
\cline { 2 - 10 } & $V M$ & $F C$ & Ash & Moisture & $N$ & $C$ & $H$ & $O$ & $S$ \\
\hline MC & 6.1 & 73.2 & 17.2 & 3.5 & 1.24 & 80.4 & 1.13 & 16.7 & 0.36 \\
Palm Shell & 71.3 & 18.1 & 4.0 & 6.6 & 0.40 & 60.8 & 5.74 & 32.8 & 0.04 \\
Coconut Shell & 77.8 & 15.1 & 1.1 & 6.0 & 0.17 & 58.6 & 5.78 & 35.4 & 0.03 \\
\hline 10\% palm blends & 12.5 & 66.3 & 16.4 & 4.8 & 1.18 & 73.1 & 5.8 & 19.9 & 0.05 \\
20\% palm blends & 19.3 & 60.3 & 15.1 & 5.3 & 1.02 & 72.6 & 5.9 & 20.4 & 0.05 \\
$30 \%$ palm blends & 25.0 & 55.4 & 13.5 & 6.1 & 0.91 & 71.8 & 5.8 & 21.5 & 0.04 \\
\hline $10 \%$ coconut blends & 12.2 & 65.7 & 16.1 & 6.0 & 1.11 & 73.7 & 5.7 & 19.4 & 0.05 \\
20\% coconut blends & 19.4 & 58.9 & 14.9 & 6.8 & 0.95 & 70.7 & 5.6 & 22.7 & 0.05 \\
30\% coconut blends & 27.9 & 53.2 & 12.4 & 6.5 & 0.84 & 68.5 & 5.7 & 24.9 & 0.04 \\
\hline
\end{tabular}

Metallurgical coke (MC) is commonly used as a carbon material in several metallurgical processes and the amount of $\mathrm{MC}$ varies with the practice and equipment used. ${ }^{17)}$ However, coke consumption needs to be reduced due to problems associated with green house gas emissions and this can be achieved by replacing it with alternative environmentally friendly sources of carbon. ${ }^{13)}$

Coke and agricultural waste materials are consumed by both thermal decomposition (devolatilization) and char oxidation. Agricultural waste materials are composed of cellulose, hemicelluloses and lignin carbon structures, which different from the turbostatic structure found in coke. Compared to coke, the agricultural waste materials are characterized by higher content of volatile matter. This indicates that the wastes are easier to ignite and burn and the combustion is expected to be rapid. The high volatile matter content is expected to affect the overall combustion process. ${ }^{18,19)}$

This paper focuses on the fundamental science underlying the use of palm shell and coconut shell wastes in their role as partial replacement of coke in metallurgical processes. Blends of different proportions of coke and $\mathrm{palm} /$ coconut shell, from 10 to $50 \%$ agricultural wastes, are subjected to combustion reactions in air atmosphere $\left(80 \% \mathrm{~N}_{2}+20 \% \mathrm{O}_{2}\right)$ in bench scale reactors such as DTF (Drop Tube Furnace). Analytical tools such as NMR $\left({ }^{13} \mathrm{CP}\right.$ MAS Nuclear Magnetic Resonance), XRD (X-ray Diffraction) and SEM (Scanning Electron Microscopy) are used to analyse and understand the structural transformations following high temperature gas phase reactions. Quantification of physical changes through surface area measurements is performed using Brunauer-Emmet-Teller (BET) technique, with nitrogen used as adsorbent due to its ability to penetrate the carbonaceous pores and channels. Surface area measurements are used to estimate the changes occurring after the combustion reaction of coke and its blends with palm shell and coconut shell wastes, respectively.

Findings from these studies could be significant in paving the way for innovative utilization of agricultural waste in metallurgical processes.

\section{Experimental}

\subsection{Material Characteristics}

Coke, the conventional carbon material used in metallur-
Table 2. Ash analysis of MC and agricultural waste (wt.\%).

\begin{tabular}{c|c|c|c}
\hline Compound & Metallurgical Coke (\%) & Palm Shell (\%) & Coconut Shell (\%) \\
\hline $\mathrm{SiO}_{2}$ & 57.4 & 55.7 & 16.1 \\
$\mathrm{Fe}_{2} \mathrm{O}_{3}$ & 5.9 & 20.5 & 46.8 \\
$\mathrm{Al}_{2} \mathrm{O}_{3}$ & 26.5 & 8.9 & 1.3 \\
$\mathrm{TiO}_{2}$ & 1.2 & 0.3 & 0.09 \\
$\mathrm{P}_{2} \mathrm{O}_{5}$ & 0.6 & 4.1 & 1.9 \\
$\mathrm{Mn}_{3} \mathrm{O}_{4}$ & 0.3 & 0.2 & 0.4 \\
$\mathrm{CaO}$ & 4.1 & 2.2 & 3.5 \\
$\mathrm{MgO}$ & 0.6 & 2.9 & 2.4 \\
$\mathrm{Na}_{2} \mathrm{O}$ & 0.2 & 1.1 & 7.9 \\
$\mathrm{~K}_{2} \mathrm{O}$ & 0.7 & 4.0 & 16.9 \\
$\mathrm{SO}_{3}$ & 2.5 & 1.1 & 2.7 \\
\hline
\end{tabular}

gical processes was provided by OneSteel, Sydney Mill. Palm shell and coconut shell wastes were supplied by The University of Malaysia Perlis, Perlis, Malaysia. The proximate (air dry base, \%) and ultimate (dry ash free, \%) analyses were carried out at Amdel Laboratories and Technical Services, NSW after Australian standards. The particle sizes used in the present study are in the range between $0.045-$ $0.063 \mathrm{~mm}$ for coke and $0.09-0.125 \mathrm{~mm}$ for agricultural wastes based on the previous literature. These size are consistent with the particle size used in drop tube furnace experiments. ${ }^{4,20)}$ The samples for the experiments were prepared by mixing $\mathrm{MC}$ and agricultural waste particles in various proportions, $90 \%$ coke- $10 \%$ agricultural waste, $80 \%$ coke$20 \%$ agricultural waste, $70 \%$ coke- $30 \%$ agricultural waste, $60 \%$ coke- $40 \%$ agricultural waste and $50 \%$ coke- $50 \%$ agricultural waste. Tables 1 and $\mathbf{2}$ illustrate the chemical characteristics of the samples used in this study.

The volatile matter (VM) content increases with increasing proportion of agricultural waste materials. The VM content is in a similar range for both palm and coconut shell blends (Table 1). A higher content of oxygen is introduced by the blends compared to coke, while the amount of hydrogen is clearly higher with palm and coconut shell addition in the blends. Hydrogen will enhance the reactivity, thus a better combustion performance is expected with blending. 
The composition of the ash is an important indicator of the reactivity of materials. ${ }^{21)}$ Iron, ${ }^{22)}$ sodium and potassium oxides are known to act as catalysts in gas phase reactions. Hematite $\left(\mathrm{Fe}_{2} \mathrm{O}_{3}\right)$ and $\left(\mathrm{Na}_{2} \mathrm{O}, \mathrm{K}_{2} \mathrm{O}\right)$ was found to catalyse the reaction. ${ }^{23)}$ The alkali metals in agricultural waste materials are expected to vaporise faster compared to coke due to the weak bonding structure present in the agricultural waste materials. The composition of the ash present in the studied samples (Figs. 1 and 2) show an increase in the proportion of alkali metal in both agricultural waste materials compared to coke.

The cellulose and hemicellulose content in the agricultural waste materials (Fig. 3) may enhance the combustion characteristics and decomposition of lignin since the cellulose compounds have structures characterized by branched chains of polysaccharides with no aromatic compounds, which can be easily volatilized.

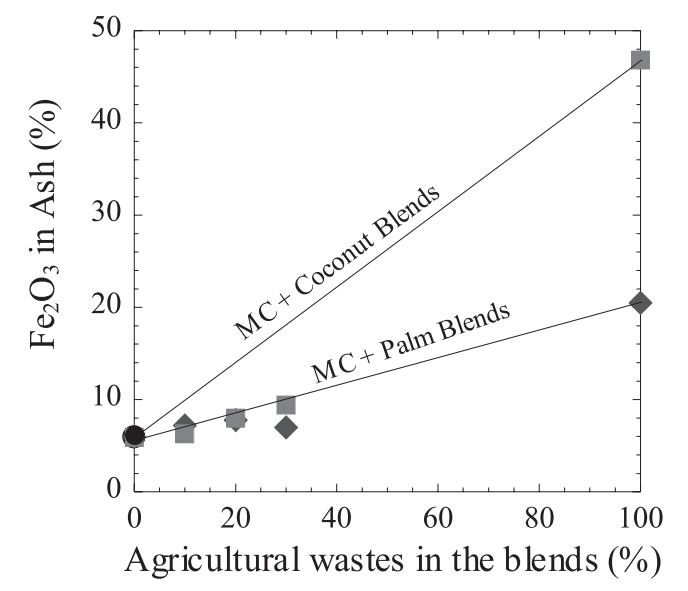

Fig. 1. $\mathrm{Fe}_{2} \mathrm{O}_{3}$ component presents in $\mathrm{MC}$ and $\mathrm{MC}$ - palm/coconut shell blends.

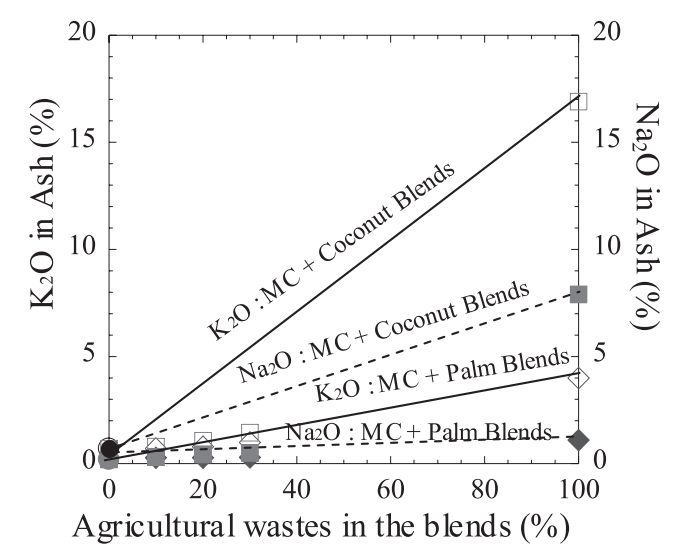

Fig. 2. $\mathrm{K}_{2} \mathrm{O}$ and $\mathrm{Na}_{2} \mathrm{O}$ components present in $\mathrm{MC}$ and $\mathrm{MC}$ - palm/ coconut shell blends.

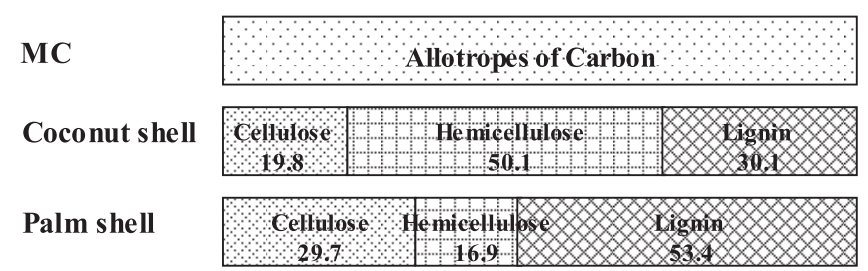

Fig. 3. Cellulose, hemicellulose and lignin contents of palm shell and coconut shell. ${ }^{61)}$

\subsection{Drop Tube Furnace (DTF)}

A drop tube furnace (DTF) $)^{24,25)}$ is a vertical type of furnace used for studying the gas phase reactions of carbonaceous materials with application in metallurgical processes. $\mathrm{MC}$ and agricultural waste particles are heated at a heating rate of $10^{4} \mathrm{~K} / \mathrm{s}$ after injecting from the top through a watercooled injector at the rate of $1.5 \mathrm{~g} / \mathrm{min}$ and a screw feeder in a reaction zone at $1200^{\circ} \mathrm{C}$.

A Brooks mass flow controller was used to adjust the gas composition and flow rate. The combusting air composition was maintained at $80 \% \mathrm{~N}_{2}$ and $20 \% \mathrm{O}_{2}$ at a steady gas flow rate of $1.0 \mathrm{~L} / \mathrm{min}$ providing fuel lean combustion conditions. The residual particles were collected at the bottom of the DTF. The residual carbon content was measured by using a LECO analyzer. The ash content of the char samples was estimated using a muffle furnace available at UNSW laboratory. The combustion efficiency was calculated using the ash tracer method ${ }^{26}$ often used for this purpose. ${ }^{27-29)}$ The notion of the ash tracer method is that the amount of the ash from the solid fuels and their derived chars is conserved (Eq. (1)):

$$
\eta=\left[\left(1-\left(\mathrm{A}_{0} \mathrm{C}_{i} / \mathrm{A}_{i} \mathrm{C}_{0}\right)\right] \times 100 \%\right.
$$

Where $\mathrm{A}_{0}$ and $\mathrm{C}_{0}$ are the ash and carbon content of the raw sample (\%) and $\mathrm{A}_{i}$ and $\mathrm{C}_{i}$ represent the ash and carbon content of the combusted char samples. Under the current DTF conditions, the coke burnout value was observed to be in the same range as previously reported. ${ }^{24,30)}$ This technique is similar to that used by Zaharia et al. ${ }^{25)}$ while the combustion efficiency value of $\mathrm{MC}$ attained in this study $(\sim 10$ wt.\%) is comparable with the previous study. The DTF burnout of coke is primarily used to compare the effect of agricultural waste/coke properties on their combustion efficiency under a controlled combustion performance. The DTF tests were repeated 5 times for consistency at $1200^{\circ} \mathrm{C}$ in the presence of $80 \% \mathrm{~N}_{2}, 20 \% \mathrm{O}_{2}$ by using different proportions of agricultural waste/coke blends.

\subsection{Sample Characterizations}

Chemical characterization of the samples was done using X-ray Diffraction (XRD) and Nuclear Magnetic Resonance Spectroscopy (NMR). XRD analysis was performed using Philips Multipurpose diffractometer (MPD Scherrer) to study the structural characteristics of the main materials used in the present study. The diffraction patterns were captured at an angular range of $10-55^{\circ}(2 \theta)$, a step size of $0.02^{\circ}$, and a rate of $0.5^{\circ} / \mathrm{min}$. The observed intensity was corrected for polarization and then converted to reduced intensity. For the NMR spectroscopy, a Bruker Avance III 300 Solid State spectrometer was used operating at a frequency of $75.5 \mathrm{MHz}$ (sodium frequency of $79.4 \mathrm{MHz}$ ), at ambient temperature with carbon resonance. The spinning speed was $4 \mathrm{kHz}$ while $4 \mathrm{~mm}$ rotors of $\mathrm{ZrO}_{2}$ were used. The NMR spectra were acquired using a cross-polarization (CP) sequence for signal enhancement, and high-power ${ }^{1} \mathrm{H}$ gated decoupling. The obtained data was analyzed with TOPSPIN software provided by Bruker.

Physical chracterization of the samples was performed using quantitative Brunauer-Emmett-Teller (BET) and qualitative analysis Scanning Electron Micoscopy (SEM). The samples were outgassed at $200^{\circ} \mathrm{C}$, at least $24 \mathrm{~h}$ prior to 

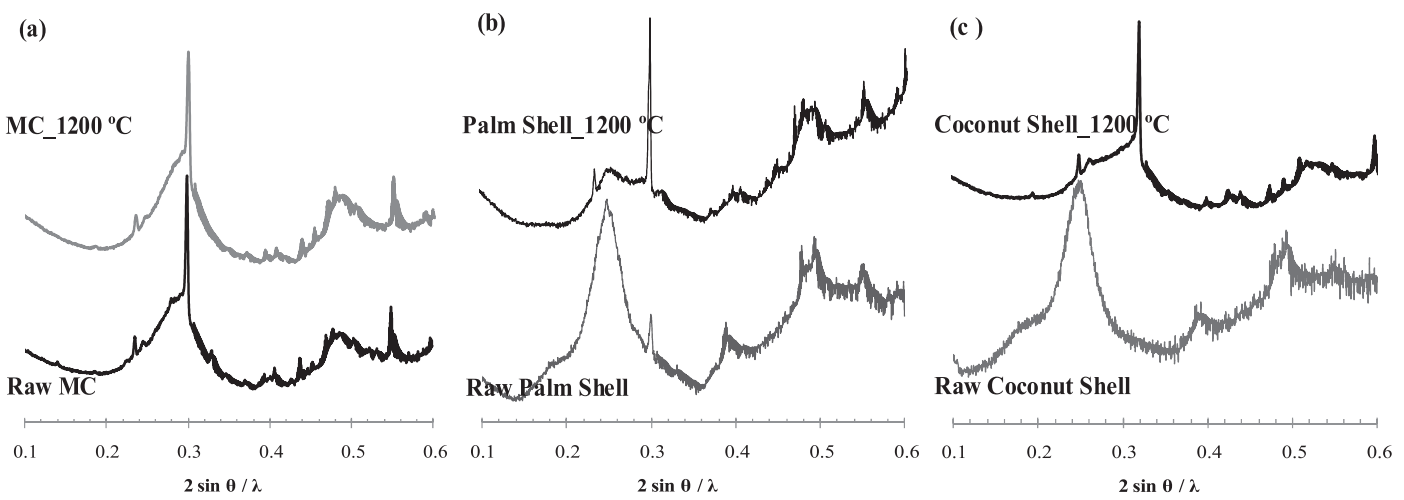

Fig. 4. XRD patterns displaying peak intensities of (a) raw $M C$ and $M C$ after combustion, (b) raw palm shell and palm shell after combustion and (c) raw coconut shell and coconut shell after combustion at $1200^{\circ} \mathrm{C}$ in $80 \% \mathrm{~N}_{2}, 20 \% \mathrm{O}_{2}$.

the measurement. Original and combusted samples were examined by Hitachi 3400X scanning electron microscope (SEM) operating at an accelerating voltage of $20 \mathrm{kV}$. The cross section of the char samples was observed by cold mounting in resin followed by polishing to a 1200 grade using $\mathrm{SiC}$ paper and $1 \mu \mathrm{m}$ grade diamond paste on a lap cloth polishing wheel.

\section{Results and Discussion}

\subsection{Effect of Chemical Properties}

The structure of the samples was observed using X-ray diffraction technique to highlight the changes occurring following high temperature gas phase reaction. Figure 4 shows the reduced intensity profile of raw agricultural wastes (palm and coconut shells) and coke. The combusted residues are also presented (Fig. 4) for comparison. Coke is known to contain short range graphite like structure (Fig. 4(a)), i.e. crystalline carbon, of the order of nanometres $(\sim 2 \mathrm{~nm}) .^{31)}$ The crystalline carbon has an intermediate structure between graphitic and amorphous, also called "turbostatic" or random layer lattice structure, as suggested by Biscoe and Warren. ${ }^{32)}$ Both agricultural wastes have a highly amorphous structure displaying a very broad diffused spectrum with asymmetric features of the 002 band, characterized by a wide range of carbon lattice spacing.

Before combustion, there is no crystalline order in the agricultural waste materials (Figs. 4(b) and 4(c)). Little additional ordering (graphitization) is seen to take place after devolatilization and the previous published literature supports this findings. ${ }^{33)}$ Graphitization depends on the ability of carbon crystallites to align and coalesce. Mobility is enhanced by hydrogen whereas oxygen hinders mobility by developing highly cross-linked rigid carbon structures. Although agricultural wastes contain high levels of oxygen (Table 1) compared to coke, the graphitic structures do develop in agricultural chars (Figs. 4(b) and 4(c)).

During combustion, all carbon atoms are exposed to oxidizing gas and the amorphous carbon which is more reactive is liberated as volatiles. The structural disorder may lead to higher reactivities of agricultural waste since more edge carbon are available. ${ }^{34)}$

\subsection{Effect of Carbon Structure}

${ }^{13} \mathrm{C}$ NMR spectroscopy was used to identify the various carbon groups in the present agricultural waste materials

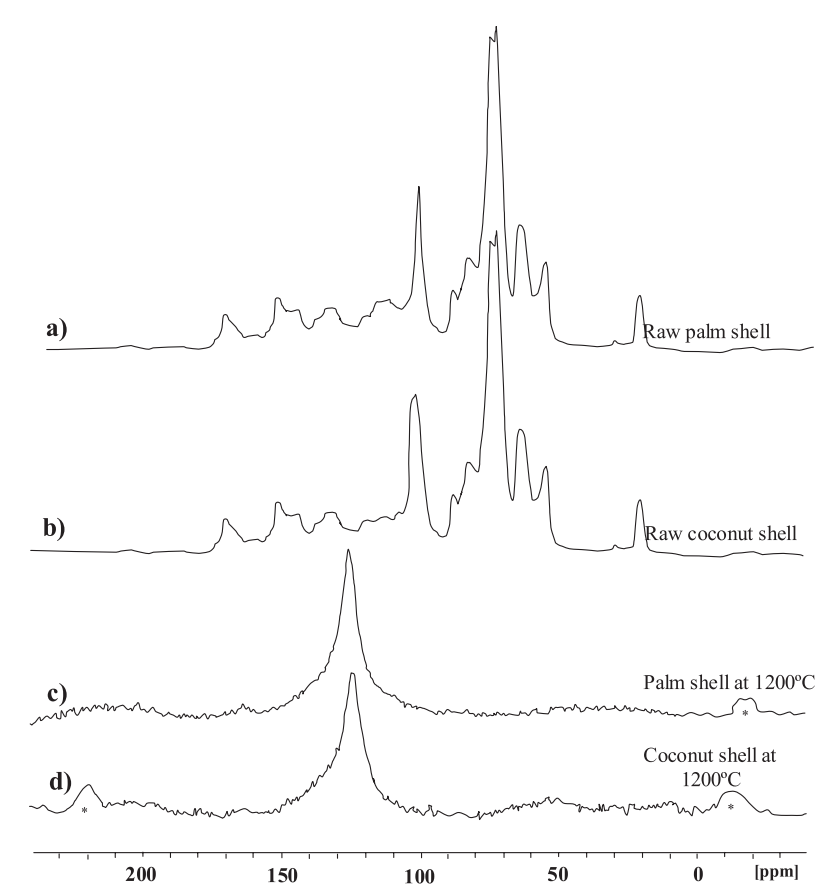

Fig. 5. Spectrum of CP/MAS ${ }^{13} \mathrm{C}$ NMR of the agricultural waste (a) raw palm shell, (b) raw coconut shell, (c) palm shell char and (d) coconut shell char at $1200^{\circ} \mathrm{C}$ in a drop tube furnace $\left[80 \% \mathrm{~N}_{2}, 20 \% \mathrm{O}_{2}\right]$ (* spinning sideband).

and combusted char samples. The present study investigates the influence of high temperature and air atmosphere on the residual mass of the agricultural wastes by comparing the carbon groups remaining after combustion. Figures 5(a) and 5(b) summarizes the results obtained from the NMR spectra of the original agricultural waste samples.

Both agricultural waste materials (Figs. 5(a) and 5(b)) show a peak at $22 \mathrm{ppm}$ assigned to the acetyl methyl groups of hemicelluloses. At $56 \mathrm{ppm}$, most of original agricultural waste samples show a peak attributed to the methoxy groups of lignin. The peak at $65 \mathrm{ppm}$ is assigned to the aliphatic C6 carbons of crystalline cellulose. In the region of 72 and 75 ppm, the agricultural waste samples have the highest peak, corresponding to the C-2, C-3, and C-5 carbons of cellulose.

The agricultural waste samples show C-4 amorphous and crystalline cellulose at 84 and 89 ppm, respectively, while at $105 \mathrm{ppm}$ a sharp peak appears indicating the presence of anomeric carbon of sugars. The signals in the region of 116 ppm represent the lignin quaiacyl C-3 and C-5 only detected in palm shell. Lignin syringyl C-1, syringyl C-5, and quai- 
acyl C-2 are detected for all agricultural waste samples exhibiting a broad line in the region between 134 and 137 ppm. The signals at $153 \mathrm{ppm}$ are assigned to syringyl C-3 and syringyl C-5. In case of palm shell, the signal at 162 ppm corresponds to 4-hydorxyphenyl C-4. Both agricultural waste materials show carbonyl groups $(\mathrm{COOH})$ of hemicelluloses seen at $173 \mathrm{ppm}$ which are well known to have a high reactivity. ${ }^{35)}$

Figures 5(c) and 5(d) show the NMR spectra of the residual chars derived from combustion of agricultural waste materials. Both char samples prepared at $1200^{\circ} \mathrm{C}\left(80 \% \mathrm{~N}_{2}\right.$, $20 \% \mathrm{O}_{2}$ ) show one peak at $124-126$ ppm assigned to aromatic lignin (124 ppm-issuing from polyaromatic hydrocarbons). The aromaticity of the chars increased due to the loss of the less stable aliphatic groups. From the agricultural wastes spectra, we can conclude that the step of aromaticity is considerable. The broad resonances in Figs. 5(c) and 5(d) demonstrate the amorphous nature of the chars due to the presence of free radicals and the complex structure of this highly dipolar coupled materials.

Different authors have reported the changes in composition of woody materials following thermal treatment. ${ }^{36)} \mathrm{New}$ carbon groups were seen to evolve. However, at the end temperatures of pyrolysis $\left(600^{\circ} \mathrm{C}\right)$, only aromatic groups were left behind. ${ }^{37-39)}$ Sharma et al. ${ }^{40}$ showed that the amount of aromatic carbons in a lignin char is less than in the original sample material. The aromatic component of lignin is very resistant to thermal degradation, and the resulting char is highly refractory. The lignocellulosic structure was lost and transformed to polycyclic material with a preponderance of aromatic structures while the proton amounts are decreased drastically as the temperature of treatment increases. All cellulose and lingo-cellulosic materials under thermal treatment with final temperatures between 800 and $1000^{\circ} \mathrm{C}$ were seen to undergo structural transformation, resulting in a more ordered structure. ${ }^{39)}$ As in the present study, residues reaches end temperature of $1200^{\circ} \mathrm{C}$, such a transformation is expected for the employed agricultural waste materials.

The ${ }^{13} \mathrm{C}$ NMR spectra recorded for coke before and after combustion are shown in Figs. 6(a) and 6(b). The comparison between the spectra shows only slight modifications. The spectra can generally be divided into two main chemical region: aliphatic carbons $(0-90 \mathrm{ppm})$ and aromatic carbons (90-220 ppm), including carbonyl/carboxyl and

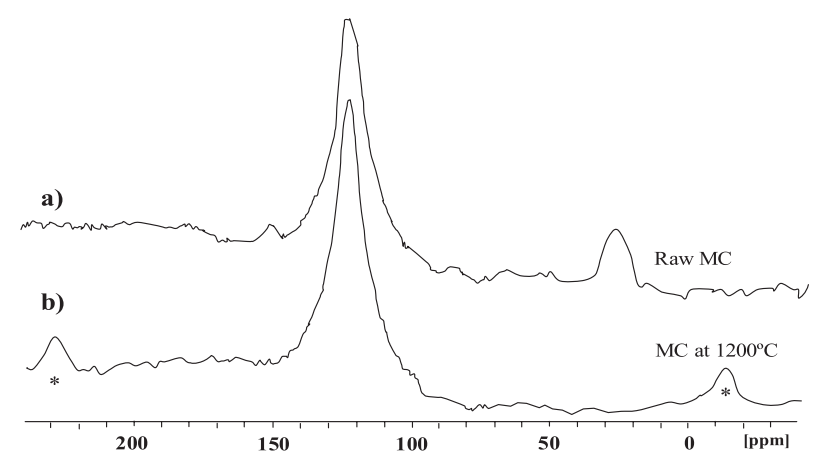

Fig. 6. $\mathrm{CP} / \mathrm{MAS}{ }^{13} \mathrm{C}$ NMR spectra of (a) raw $\mathrm{MC}$ and (b) $\mathrm{MC}$ at $1200^{\circ} \mathrm{C}$ in a drop tube furnace $\left[80 \% \mathrm{~N}_{2}, 20 \% \mathrm{O}_{2}\right]$ (* spinning sideband). phenolic groups. Figure 6(a) shows aromatic C group, which are aromatic $-\mathrm{C}-\mathrm{H}$ groups $(124 \mathrm{ppm})$ and oxygenated structures $-\mathrm{C}-\mathrm{O}-(156 \mathrm{ppm})$.

The TOSS spectrum shows a broad peak at $32 \mathrm{ppm}$ with two small shoulders centered at around $25 \mathrm{ppm}$, which can be assigned to $\mathrm{CH}_{2}$ attached to the aromatic rings and complex aliphatic carbon. ${ }^{41)}$ However, after high temperature gas phase reaction, coke (Fig. 6(b)) showed the destruction of aliphatic groups and the formation of alcohols, ethers, and carbonyl groups revealing more aromatic $\mathrm{C}$ and $\mathrm{CH}$ at $128 \mathrm{ppm}$.

Less changes were seen in the residual coke samples while the agricultural waste materials showed significantly different spectra following the high temperature reaction in the DTF. The loss of lignocellulosic structure present in palm and coconut shells (Fig. 5) might lead to higher combustion peformances because the strength of molecular structures are easier to break compared to coke carbon structure which is more aromatic (Fig. 6) and the bonds are stronger.

\subsection{Effect of Blending on Gas Phase Reaction}

To quantify the combustion performances of coke and coke/agricultural blends in various proportion, the ash conversion equation (Eq. (1)) is used. Higher burnout values are developed by the blends when compared to the burnout found in the parent material. Coke burnout estimated a values of $10 \%$ while palm shells attained $14.3 \%$ (Fig. 7). Coconut shells showed slightly increased burnout of $15.1 \%$. By replacing coke with agricultural materials content in the blends, an increase in the burnout is seen. Figure 7 shows the combustion efficiency of MC and their blends with 10$50 \%$ agricultural wastes at a combustion temperature of $1200^{\circ} \mathrm{C}$ with $80 \% \mathrm{~N}_{2} ; 20 \% \mathrm{O}_{2}$.

Both agricultural wastes showed a similar trend in combustion performance and this might be attributed to their similar structure (lignocellulosic structure) as seen in the NMR spectra. However, a sharp increase was observed for $10 \%$ coconut/coke blend (Fig. 7), while a marginal increase is seen afterwards. On the other hand, palm shell blends increases gradually, such an increase is seen for the blends with palm shell of up to $30 \%$, afterwards only marginal changes are developed. The slight change in the coke carbon

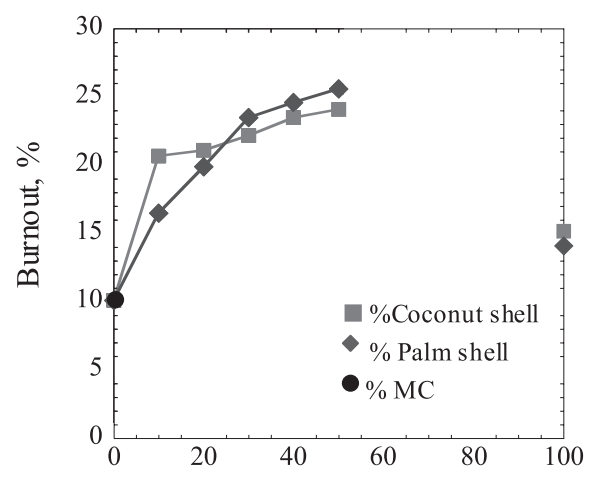

Agricultural waste content in the blends (\%)

Fig. 7. Comparison of blending $\mathrm{MC}$ with varying palm shell and coconut shell contents with the raw coke on the combustion at $1200^{\circ} \mathrm{C}, 80 \% \mathrm{~N}_{2} ; 20 \% \mathrm{O}_{2}$. 
structure following combustion is consistent with lower combustion performance when compared to the agricultural blends.

Minerals, such as iron and alkali metals in agricultural waste contribute to the mineral matter in the blends and influence combustion. From previous study, the influences of catalytic mineral phases in coke reactivity were investigated. ${ }^{42-44)}$ Grigore et al. identified Australian coke containing more than 7 wt.\% of iron oxide in the ash having catalytic effects. Iron oxide content showed significant variation in the 3 samples studied in Table 2 and Fig. 1. The ash of the coconut shell has $\mathrm{Fe}_{2} \mathrm{O}_{3}=46.8$ wt.\% while the $\mathrm{Fe}_{2} \mathrm{O}_{3}$ present in the palm shell ash equals to $20.5 \mathrm{wt} . \%$. These values are higher than the $\mathrm{Fe}_{2} \mathrm{O}_{3}(5.7$ wt.\%) content in coke, thus could influence the combustion performance of the blends. Backreedy et al. ${ }^{45)}$ studied the mechanism on the formation of a $\mathrm{C}$ - metal bond during devolatilisation. The alkali metals, $\mathrm{C}-\mathrm{O}-\mathrm{M}$ bond (where $\mathrm{M}$ can be $\mathrm{Fe}, \mathrm{Na}, \mathrm{K}$ or $\mathrm{Ca}$ ) was seen to be formed which effected the $\mathrm{C}-\mathrm{C}$ bond and hence catalysed the gas phase reaction. ${ }^{46)}$ Yamashita et $a l .{ }^{47)}$ found that during devolatilization, the chemical form of iron species changed stepwise as follows with high temperature. Thus, a rapid increase of the burnout is expected in the following order: coconut shell blends $>$ palm shell blends $>$ MC.

Moreover, alkali metals such as potassium and sodium in coke are associated with aluminosilicate in an unexchangeable ion form and they are believed to be catalytically inactive. ${ }^{48)}$ Table 2 showed the presence of $\left(\mathrm{Na}_{2} \mathrm{O}, \mathrm{K}_{2} \mathrm{O}\right)$ in coke ash is less than 1 wt.\%. On the other hand, palm shell contains $\left(\mathrm{Na}_{2} \mathrm{O}=1.1\right.$ wt. $\% ; \mathrm{K}_{2} \mathrm{O}=4.0$ wt.\%) and coconut shell has higher content of $\mathrm{Na}_{2} \mathrm{O}=7.9$ wt. $\%$ and $\mathrm{K}_{2} \mathrm{O}=16.9$ wt.\%. By blending coke with agricultural wastes, the presence of alkali $\left(\mathrm{Na}_{2} \mathrm{O}, \mathrm{K}_{2} \mathrm{O}\right)$ in the agricultural wastes ash (Fig. 2) might catalytically enhance the combustion performance of the blends. ${ }^{49)}$ Sodium ions are very small and can penetrate into the agricultural waste texture and break the intermolecular hydrogen bridges under high temperature. These ions can react with cellulose through active alcohol groups of cellulose. ${ }^{50,51)}$ The inorganic elements are located at the edge sites of the carbon layer and at the vacancies between the carbon layers in the graphitic-like carbon building blocks of coke/agricultural blends also known as carbon active sites. ${ }^{52-54)}$ Their location allows them to catalytically enhance oxygen reactivity of neighbouring carbon atoms in the carbon matrix. ${ }^{52,55)}$

The reactivity of agricultural waste materials also might be influenced by the activation of the $-\mathrm{O}$ - groups present in the structure. The cellulose, hemicellulose and lignin (Fig. 3), which constitute the macromolecular structure of the agricultural and other woody materials, are linked together with relatively weak ether bonds $(\mathrm{R}-\mathrm{O}-\mathrm{R}$, bond energy of $380-420 \mathrm{~kJ} \mathrm{~mol}^{-1}$ ). It has been reported by Blajez and Kosik, ${ }^{33)}$ that these bonds are less resistant to heat at temperatures as low as $\left(400-500^{\circ} \mathrm{C}\right)$. In contrast, the immobile structure (MC carbon structure), which mostly comprised of dense polycyclic aromatic hydrocarbons linked together by $\mathrm{C}=\mathrm{C}$ (aromatic ring) bonds with bond energy of $1000 \mathrm{~kJ} \mathrm{~mol}^{-1}$ are more resistant to the heat. ${ }^{6,56,57)}$ The difference in the strength of molecular structure of the fuels might be responsible to for such behavior.
The amount of volatile matter present in the carbonaceous material blends are also known to influence the burnout values to a certain extent. ${ }^{30)}$ Proximate analysis of the palm shell/coke and coconut shell/coke blends suggests an increase in volatile matter with higher agricultural content in the blend (Table 1). However, the volatile matter present in both types of blends, with the two types of waste materials are similar. The volatile content could also play an important role in influencing the combustion performance of the present materials.

\subsection{Effect of Physical Properties}

The presence of agricultural waste materials could influence char properties in many ways. The burnout improvement of the blends could be attributed to the modification of the physical structure of the resulting char. Physical chracterization of the samples were performed using quantitative (BET) and qualitative analysis (SEM).

Figure 8 shows the graph of micropore surface area as a function of carbonaceous material studied and reaction stage. The results demonstrated minor changes in the BET surface area for coke, from 31.6 to $34.9 \mathrm{~m}^{2} / \mathrm{g}$, while a high surface area had developed for coconut shell blends after the reaction in DTF i.e., from 26.3 to $36.7 \mathrm{~m}^{2} / \mathrm{g}$ for $10 \%$ coconut shell, from 13.9 to $25.7 \mathrm{~m}^{2} / \mathrm{g}$ for $20 \%$ coconut shell, and from 7.4 to $17.2 \mathrm{~m}^{2} / \mathrm{g}$ for $30 \%$ coconut shell in Fig. 8(b). In the case of coconut shell blends, the initial increase in combustion efficiency is supported by the first increase in surface area (high surface area $=36.7 \mathrm{~m}^{2}$ in Fig. 8(b)) and this followed by only small increase in combustion efficiency (Fig. 7).

Palm shell (Fig. 8(a)) presented well-defined differences
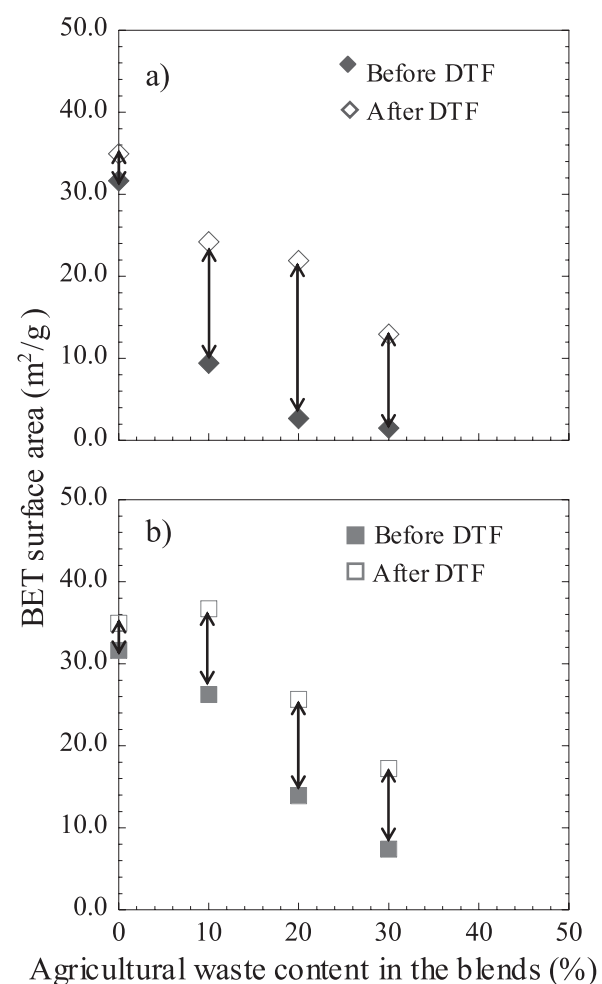

Fig. 8. Changes in micropore surface area (a) palm shell and (b) coconut shell before and after combustion in DTF as a function of the agricultural wastes content in the blend. 
in the before and after reaction samples with values from 9.4 to $24.2 \mathrm{~m}^{2} / \mathrm{g}$ for $10 \%$ palm shell, from 2.7 to $21.9 \mathrm{~m}^{2} / \mathrm{g}$ for $20 \%$ palm shell and from 1.5 to $12.0 \mathrm{~m}^{2} / \mathrm{g}$ for $30 \%$ palm shell. The differences in surface area before and after reaction in the DTF are attributed to pores opening up with volatile matter evolution. The BET surface area of the blend char samples was higher compared to the surface area of MC. The surface area of the MC did not change significantly as is has already been heat treated.

The development of porosity in the residual chars depends upon the amount of the volatile removed and the subsequent structural changes of the residual carbon. Agricultural waste materials contain a high amount of volatiles; when in conjunction with the coke matrix, structural and physical changes might appear, because of the release of volatiles.

The effect of physical transformations was studied through qualitative SEM imaging. Figure 9 shows the morphology of $100 \%$ metallurgical coke. Bright white spots are present, believed to be residual ash (Figs. 9(a) and 9(b)) because $\mathrm{MC}$ has high ash content in its composition (see Table 1). The ash is known to accumulate at the receding surfaces of the burning char thus impeding pore enlargement. Consequently oxygen diffusion might be delayed, and a lower combustion performance is expected. The cross-sections of the coke particles before and after combustion in DTF are taken to support the above statement and are illustrated in Figs. 9(c) and 9(d), respectively. The morphology of the raw coke shows a very porous matrix characterized by bright white well defined edges (Fig. 9(c)). Following combustion, no significant changes are seen (Fig. 9(d)) in the coke particle, which is expected based on the BET surface area (Fig. 8) measurements detailed earlier and the amount of volatiles available in the raw sample.

Typical SEM micrographs of palm shell and its corresponding char obtained at $1200^{\circ} \mathrm{C}$ in $20 \% \mathrm{O}_{2}$ and $80 \% \mathrm{~N}_{2}$ mixed atmosphere are illustrated in Figs. 10(a)-10(d). Ordered compact cells seem to define the raw palm shell structure with small pores dispersed throughout (Fig. 10(a)). The cross-section of the shell shows isodiametric polygonal flattened cells with well-defined lumen arranged in a honeycomb like pattern (Figs. 10(a) and 10(c)). The combustion
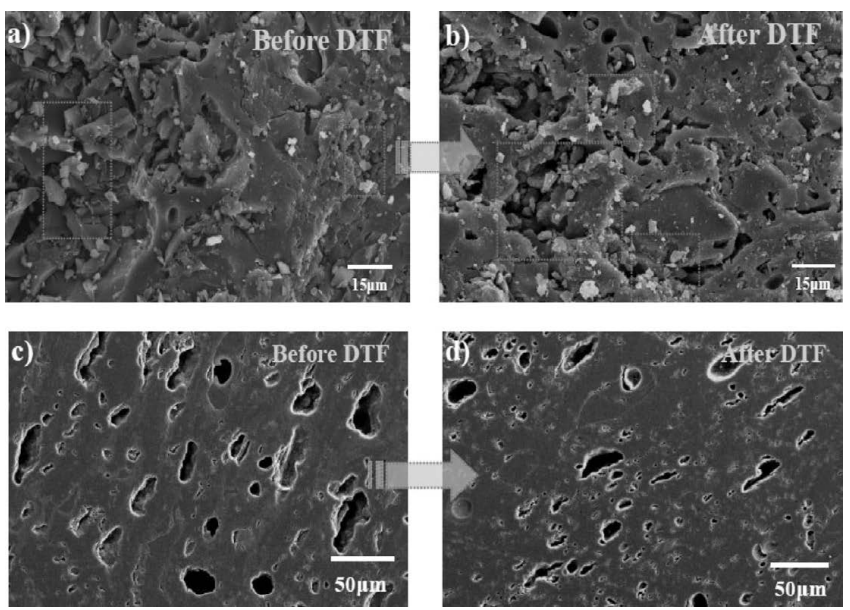

Fig. 9. SEM micrograph of (a) raw MC, (b) MC after combustion at $1200^{\circ} \mathrm{C}$ in DTF, (c) cross-sectional image of raw MC and (d) cross-section of MC char. stage is expected to cause noticeable changes in the shells' structure. Micrographs of the external surfaces of the char obtained at $1200^{\circ} \mathrm{C}$ (Fig. 10 (d)) indicate progressive destruction of the cell lumen and rupture of walls during combustion.

The cellular structures were open-up seen in Fig. 10(c) showed the distinctive features with porous networks which are attributed to the evaporation of volatile material. Cetin, et al. ${ }^{58)}$ while studying the effect of pyrolysis on the structure of several agricultural char, found that the cell structure practically did not exist after devolatilization. He believed the lack of cell structure in high heating rate chars could be assigned to melting of the cell structure and, thereby, occurrence of plastic transformations.

Further on, SEM micrographs of coconut shell and its residual mass after combustion are presented in Figs. 11(a)-
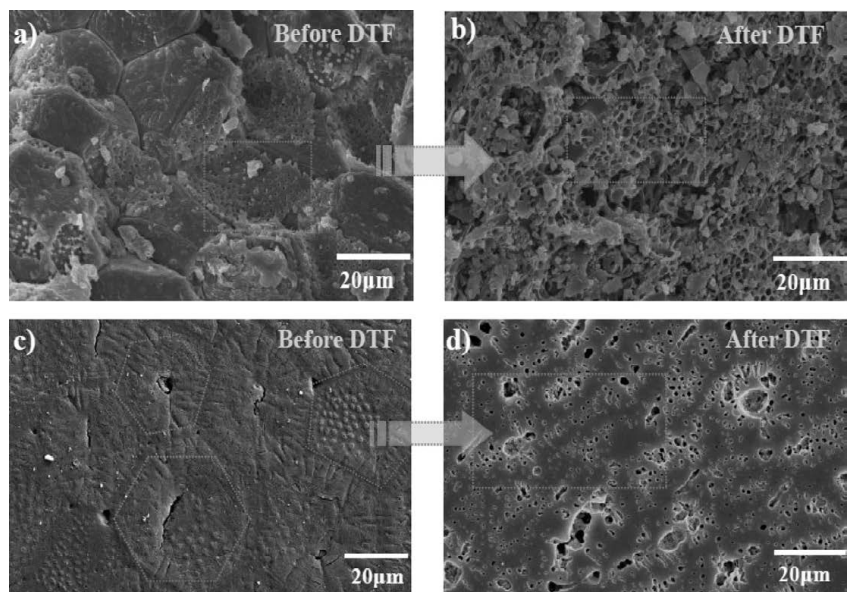

Fig. 10. SEM micrograph of (a) raw palm shell, (b) palm shell after combustion at $1200^{\circ} \mathrm{C}$ in DTF, (c) cross-sectional image of raw palm shell and (d) cross-section of palm shell char.
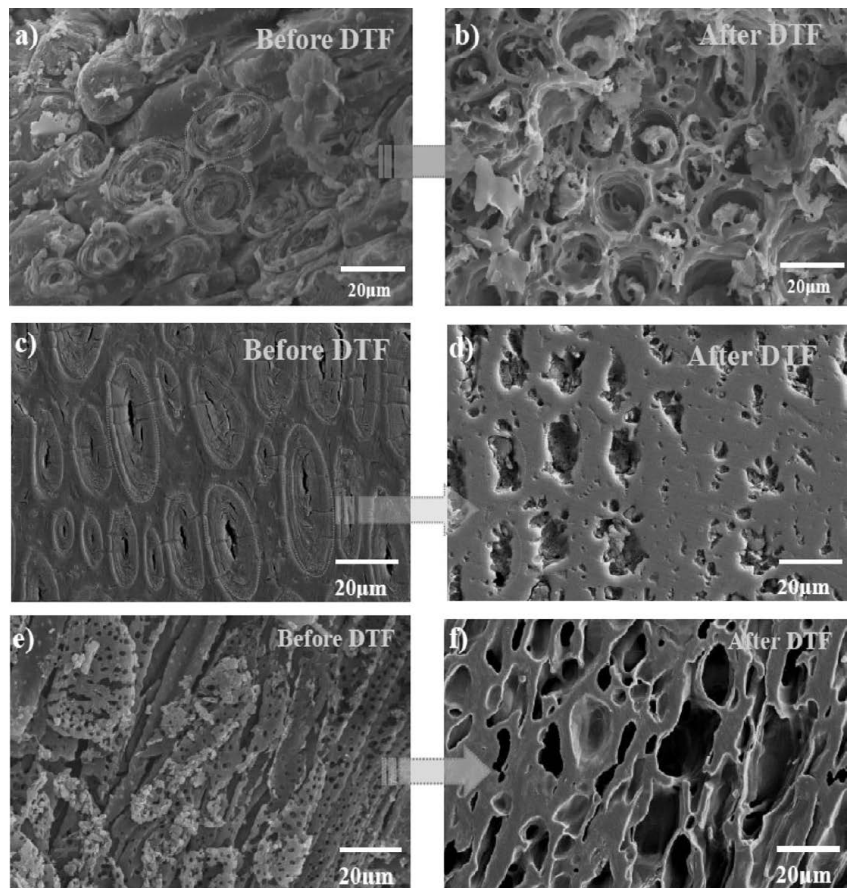

Fig. 11. SEM micrograph of transverse section of (a) raw coconut shell, (b) coconut shell after combustion at $1200^{\circ} \mathrm{C}$ in DTF and cross-sectional images of (c) raw coconut shell, (d) coconut shell char (e) and (f) edge section of coconut shell char. 
11(f). As can be seen, the raw coconut shell and its crosssection clearly show pore structures which are made of cylinder-like tubes (Fig. 11(a)) composed of layers of several flat sheets. The cross section of the raw coconut shell gives more detail on the morphology of the cell like tubes which are seen to lie almost distinct from each other. After combustion the individual sheets of the tube walls have fused together and are no longer distinguishable from each other (Fig. 11(d)). However, the cylinders are still retained, even though the interiors are clearly being consumed. Thus, after the initial consumption of the interiors, the cylinders are not providing any further opportunities for increase, as it is difficult to find too many "edges", and the surface area is lower, compared to palm shell blends (Fig. 11(b)) where we clearly see the entire structure uniformly opening up and creating significant changes in surface area (Fig. 8).

A similar observation on the pore structure and transformations following combustion was made by Achaw et al. ${ }^{59)}$ implying that the cell structure was lost after devolatilization. The changes in the original structure of the matrix of the raw material may be attributed to the cross-linking of reactive points of the cylinders brought about by the disruption of the original polymeric structure of the precursor material (i.e. the cellulosic and lignin units of the raw material) and the subsequent reconstitution of a new matrix structure during the devolatilization. ${ }^{60)}$

The char particles resulting from the agricultural materials seem to contain a relatively greater number of large pores (Figs. 10 and 11) when compared to those in cokechar particles (Fig. 9), which may be attributed to the evolution of volatile species from the interior of the particle during the combustion process. The samples morphology is consistent with the calculated combustion efficiencies, volatile content and structural changes.

\section{Conclusions}

This study reports the effect of addition of agricultural waste on the combustion behaviour of its blends with metallurgical coke (MC).

(1) The high temperature gas phase reaction affects the chemical structure of the resulting chars. The aliphatic structure present in palm and coconut shell is consumed during combustion, leaving behind a more ordered aromatic structure.

(2) The estimated combustion efficiency values show an improvement in the performance with increasing palm and coconut shell in the blends. The volatile present in the palm and coconut shells play an important role in influencing the combustion performance in the blends.

(3) The changes in surface area are more significant when the proportion of agricultural waste materials increases. SEM micrograph supported the BET measurement showing enlarged pores develop in the agricultural waste materials. Palm shell's cell structures were seen to open up to a significant extent and structural changes were observed accompanied by higher surface area. In contrast, the structural transformations that occur in the coconut shell blends retain the cylindrical cell structures, which show a lower surface area compared to palm shell blends.

(4) The combined modification of pore and carbon structure of agricultural waste materials (palm and coconut shells) are shown to contribute to their structural transformations, which results in improvement in combustion efficiency in high temperature processes.

\section{Acknowledgments}

Financial support for the $\mathrm{PhD}$ student, Nur Farhana M. Yunos was provided by Ministry of Higher Education, Malaysia.

\section{REFERENCES}

1) T. C. Ooi, E. Aries, B. C. R. Ewan, D. Thompson, D. R. Anderson, R. Fisher, T. Fray and D. Tognarelli: Miner. Eng., 21 (2008), No. 2, 167.

2) W. Yanjia and W. Chandler: Energy Policy, 38 (2010), No. 11, 6475

3) K. Mae, I. Hasegawa, N. Sakai and K. Miura: Energy \& Fuels, 14 (2000), No. 6, 1212.

4) K. A. M. Sami: Progress in Energy Combustion Sci., 27 (2001), No. 171.

5) T. R. McLendon, A. P. Lui, R. L. Pineault, S. K. Beer and S. W. Richardson: Biomass and Bioenergy, 26 (2004), No. 4, 377.

6) H. B. Vuthaluru: Bioresource Technol., 92 (2004), No. 2, 187.

7) H. B. Vuthaluru: Fuel Proc. Technol., 85 (2004), No. 2-3, 141.

8) H. E.Gannon: The Making Shaping \& Treating of Steel, (1964), 7.

9) S. Banerjee: Iron \& Steel Heritage of India, (1997), No. 83.

10) R. C. Gupta: Mineral Proc. and Extractive Metall. Rev.: An Int. J., 24 (2003), No. 3, 203.

11) F. G. Emmerich and C. A. Luengo: Biomass and Bioenergy, 10 (1996), No. 1, 41.

12) F. G. Emmerich and C. A. Luengo: Fuel, 73 (1994), No. 7, 1235.

13) J. K. Chung: ISIJ Int., 37 (1997), No. 2, 119.

14) S. Guo, J. Peng, W. Li, K. Yang, L. Zhang, S. Zhang and H. Xia: Applied Surface Sci., 255 (2009), No. 20, 8443.

15) W. Heschel and E. Klose: Fuel, 74 (1995), No. 12, 1786

16) W. Su, L. Zhou and Y. Zhou: Chinese J. Chem. Eng., 14 (2006), No. 2, 266.

17) G. Atech: A National Approach to Waste Tyres, Commonwealth Department of Environment, Australia (2001).

18) J. Werther, M. Saenger, E. U. Hartge, T. Ogada and Z. Siagi: Progress in Energy and Combustion Sci., 26 (2000), No. 1, 1.

19) T. Ogada and J. Werther: Fuel, 75 (1996), No. 5, 617.

20) C. Meesri: A Fundamental Study on Combustion Characteristics of Pulverised Coal/Softwood Blends, PhD Thesis, The Univeristy of Newcastle, (2003).

21) D. Vogt and M. Depoux: Fuel Proc. Technol., 24 (1990), No. 99.

22) M. Lindert and R. M. C. Timmer: Ironmaking Conf. Proc., 74 (1991), 201.

23) B. v. d. Velden, J. Trouw, R. Chaigneau and J. V. d. Berg: Ironmaking Conf. Proc., 58 (1999), 275.

24) L. Lu, S. Veena, K. Chunhau and M. Alex: ISIJ Int., 42 (2002), No. 8,816

25) M. Zaharia, V. Sahajwalla, B. C. Kim, R. Khanna, N. SahaChaudhury, P. O. Kane, J. Dicker, C. Skidmore and D. Knights: Energy \& Fuels, 23 (2009), No. 5, 2467.

26) A. K. A. El-Samed, E. Hampartsoumian, T. M. Farag and A. Williams: Fuel, 69 (1990), No. 8, 1029.

27) J. Haas, M. Tamura and R. Weber: Fuel, 80 (2001), No. 9, 1317.

28) T. Suda, M. Takafuji, T. Hirata, M. Yoshino and J. Sato: Proc. Combustion Inst., 29 (2002), No. 1, 503.

29) B. Moghtaderi, C. Meesri and T. F. Wall: Fuel, 83 (2004), No. 6, 745

30) V. Sahajwalla, M. Zaharia, S. Kongkarat, R. Khanna, N. SahaChaudhury and P. O Kane: Energy \& Fuels, (2009), No. 379.

31) B. C. Kim, S. Gupta, S. H. Lee, S.M. Kim and V. Sahajwalla: Energy Fuels, 22 (2008), No. 1, 514

32) J. Biscoe and B. E. Warren: J. Appl. Phys., 13 (1942), No. 6, 364.

$33)$ C. A. Ulloa, A. L. Gordon and X. A. García: Fuel Proc. Technol., 90 (2009), No. 4, 583

34) M. J. Wornat, R. H. Hurt, N. Y. C. Yang and T. J. Headley: Combustion Flame, 100 (1995), No. 1-2, 131.

35) B. Scholze, C. Hanser and D. Meier: J. Analytical Appl. Pyro., 5859 (2001), No. 387.

36) G. N. Inari, S. Mounguengui, S. Dumarcay, M. Pétrissans and P. Gérardin: Polym. Degradation Stability, 92 (2007), No. 6, 997.

37) J. C. C. Freitas, F. G. Emmerich and T. J. Bonagamba: Chem. Mater., 12 (2000), No. 3, 711

38) Ramesh K.Sharma: Energy Fuels, 14 (2000), No. 1083.

39) M. Bardet, S. Hediger, G. Gerbaud, S. Gambarelli, J. F. Jacquot, M. F. Foray and A. Gadelle: Fuel, 86 (2007), No. 12-13, 1966.

$40)$ R. K. Sharma, J. B. Wooten, V. L. Baliga, X. Lin, W. Geoffrey Chan and M. R. Hajaligol: Fuel, 83 (2004), No. 11-12, 1469.

41) V. H. Pan and G. E. Maciel: Fuel, 72 (1993), No. 4, 451. 
42) M. Grigore, R. Sakurovs, D. French and V. Sahajwalla: ISIJ Int., 46 (2006), No. 4, 503.

43) M. Grigore: Factors Influencing Coke Gasification with Carbon Dioxide, PhD Thesis, UNSW, (2007)

44) P. L. J. Walker, M. Shelef and R. A. Anderson: Catalysis of Carbon Gasification, (1968).

45) R. I. Backreedy, J. M. Jones, M. Pourkashanian and A. Williams: Fuel, 82 (2003), No. 15-17, 2097.

46) J. M. J. R. Backreedy: Faraday Discussions, 119 (2002), No. 385.

47) H. Yamashita and A. Tomita: Ind. Eng. Chem. Res., 32 (1993), No. 3, 409.

48) R. J. Lang and R. C. Neavel: Fuel, 61 (1982), No. 7, 620

49) C. Amen-Chen, H. Pakdel and C. Roy: Bioresource Technol., 79 (2001), No. 3, 277.

50) H. Yang, R. Yan, H. Chen, C. Zheng, D. H. Lee and D. T. Liang: Combustion Flame, 146 (2006), No. 4, 605.

51) D. Vamvuka, S. Troulinos and E. Kastanaki: Fuel, 85 (2006), No. 12-13, 1763.

52) P. L. Walker Jr, R. L. Taylor and J. M. Ranish: Carbon, 29 (1991),
No. 3, 411.

53) N. M. Laurendeau: Prog. Energy Combustion Sci., 4 (1978), No. 4, 221.

54) C. A. Mims, J. J. Chludzinski, J. K. Pabst and R. T. K. Baker: J. Catalysis, 88 (1984), No. 1, 97.

55) J. A. MacPhee, J. P. Charland and L. Giroux: Fuel Proc. Technol., 87 (2006), No. 4, 335.

56) A. K. Sadhukhan, P. Gupta and R. K. Saha: Fuel Proc. Technol., 90 (2009), No. 5, 692

57) L. H. Smith, L.D. Smoot and T.H. Fletcher: The Structure and Reaction Process of Coal, Plenum Press, New York, (1994).

58) E. Cetin, B. Moghtaderi, R. Gupta and T. F. Wall: Fuel, 83 (2004), No. 16, 2139.

59) O. W. Achaw and G. Afrane: Microporous Mesoporous Mater., 112 (2008), No. 1-3, 284.

60) H. Marsh and F. R. Reinoso: Activated Carbon, (2006).

$61)$ W. M. A. W. Daud and W. S. W. Ali: Bioresource Technol., 93 (2004), No. 1, 63. 